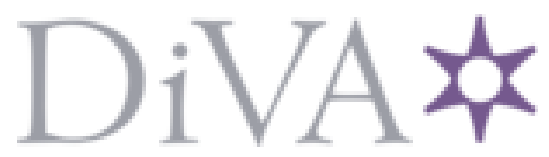

http://www.diva-portal.org

\title{
Postprint
}

This is the accepted version of a paper published in Medical Anthropology. This paper has been peerreviewed but does not include the final publisher proof-corrections or journal pagination.

Citation for the original published paper (version of record):

Lundgren, B. (2015)

Narrating narcolepsy - centering a side effect.

Medical Anthropology, 34(2): 150-165

http://dx.doi.org/10.1080/01459740.2014.962694

Access to the published version may require subscription.

N.B. When citing this work, cite the original published paper.

Permanent link to this version:

http://urn.kb.se/resolve?urn=urn:nbn:se:umu:diva-97016 


\title{
NARRATING NARCOLEPSY - CENTERING A SIDE EFFECT
}

\section{Britta Lundgren}

\begin{abstract}
The mass-vaccination with Pandemrix was the most important preventive measure in Sweden during the $\mathrm{A}(\mathrm{H} 1 \mathrm{~N} 1)$ influenza pandemic of 2009-2010, and covered 60 percent of the population. From 2010, an increased incidence of the neurological disease narcolepsy was reported, and an association with Pandemrix was affirmed for over 200 children and young adults. The parental experience of this side effect provided a starting point for a collectively shaped critical narrative to be acted out in public, but also personalized narratives of continual learning about the disease and its consequences. This didactic functionality resulted in active meaning-making practices about how to handle the aftermath - using dark humor, cognitive tricks, and making themselves and their children's bodies both objects and subjects of knowledge. Using material from interviews with parents, this mixing of knowledge work and political work, and the potential for reflective consciousness, is discussed.
\end{abstract}

Running title: Narrating narcolepsy

Key words: A(H1N1), mass-vaccination, narcolepsy, parents' narratives, side effects

Press teaser: Children and families face the consequences of managing narcolepsy as a side effect from vaccination intervention. Their experiences challenge established truths in authorities' prepandemic preparedness. 
Bionote:

Britta Lundgren received a PhD in ethnology from Umeå University in Sweden 1990 and she is now Professor at the Department of Culture and Media Studies at the same university. She is heading the research project "Epidemics, Vaccination, and the Power of Narratives". Her latest book, The Social Politics of Research Collaboration (2013) is edited with Gabriele Griffin and Katarina Hamberg. Address correspondence to Umeå University, S-901 87 Umeå, SWEDEN. Email: britta.lundgren@kultmed.umu.se 
December 13, 2013

Dear Santa,

I have only one wish for this Christmas, I wish I would get well again. I wish that everything was as before I took the vaccine for the swine flu and got narcolepsy. Then I could laugh without falling and hurting myself; I could play with my friends after school and on weekends. ... It used to be so nice when Mom and Dad gave me a goodnight hug at bedtime. Now I'm afraid of sleeping because I know I will have lots of creepy nightmares and hallucinations and I will be awake on my own several hours at night when my family sleeps. I now have 270 Swedish friends ['friends' meaning other children with narcolepsy, Author's comment], 144 friends in Finland, and 70 Irish friends who feel exactly like me and, unfortunately, I get new friends all the time. ...

This letter from 10-year old Anna, with a wish list to Santa, was part of a petition from the narcolepsy associations in Sweden, Norway, the UK, Finland, and Ireland to their respective governments, to the EU, and to the pharmaceutical company GlaxoSmithKline. ${ }^{1}$ The document was one of several ways of reacting to the fact that the vaccine Pandemrix, produced by GlaxoSmithKline, had resulted in narcolepsy as an unexpected side effect in children and young adults.

The Swedish mass-vaccination with Pandemrix was the most important preventive measure during the $\mathrm{A}(\mathrm{H} 1 \mathrm{~N} 1)$ influenza pandemic, also known as the swine flu, in 2009-2010. The National Board of Health and Welfare in Sweden (Socialstyrelsen) recommended vaccination of the entire Swedish population as a preventive measure to stop the spread of the virus and to mitigate the feared consequences. Vaccination with Pandemrix 
commenced in October 2009. Over 60 percent of the Swedish population was vaccinated, and the coverage among children was even higher (Socialstyrelsen 2011). ${ }^{2}$

During the summer of 2010, reports of narcolepsy in Swedish children and adolescents after vaccination with Pandemrix came to the attention of the Medical Products Agency (MPA). ${ }^{3}$ The cumulated number of cases of narcolepsy with cataplexy among vaccinated children and adolescents increased about four-fold during the period immediately after vaccination began in 2009, and this strengthened the evidence for an association between Pandemrix vaccination and narcolepsy. A second study in 2013 by the MPA confirmed the increased risk of narcolepsy after vaccination with Pandemrix. The risk seemed to decline gradually with increasing age. ${ }^{4}$ The Pandemrix vaccine was used extensively also in other countries $^{5}$, and narcolepsy as a side effect has been seen in Finland, Norway, the UK, and Ireland (Wijnans, Lecomte, de Vries et al. 2013).

Narcolepsy is a rare and generally underdiagnosed condition. The global prevalence is uncertain, but the incidence rate in some European countries has been estimated at 1 in 100,000 (Wijnans, Lecomte, de Vries et al. 2013). Narcolepsy is a chronic neurological disorder that mostly affects young people and is characterized by the brain's inability to control sleep-wake cycles. The most prominent symptom is excessive daytime sleepiness, and this is usually the first symptom to occur, along with sudden bouts of sleep that cannot be prevented. Other general symptoms such as cataplexy (sudden loss of voluntary muscle tone) - which can be triggered by strong emotions - and vivid dream-like images/hallucinations (hypnagogic hallucinations) and paralysis during sleep onset or when waking (sleep paralysis) are also described, together with disturbed nocturnal sleep and memory problems. Secondary effects include an inability to concentrate, learning disabilities, depression, obesity, and disturbed metabolism. The disease also has major effects on the patient's social life (Vetenskapsrådet 2012:11). 
The Pharmaceutical Insurance agency in Sweden had received 371 reports about narcolepsy after vaccination by April 2014. Three hundred of these reports concerned children and young adults (lff.se/2014/05/26/ ), and so far about 220 of these cases have been assessed as vaccine related. The Association for Narcolepsy (Narkolepsiföreningen) in Sweden claims that Pandemrix has led to at least 290 cases of narcolepsy in Sweden and 1050 cases in Europe. When reports of the side effects started to appear, medical authorities reacted with skepticism because influenza vaccines had been used for 80 years without any similar side effects. Almost four years after the mass-vaccination, it is still not known if it is a component of the adjuvanted vaccine, the influenza virus itself, genetic predispositions, or a combination of all these factors that have caused these cases of narcolepsy. Viral structures - which are an integral part of the vaccine - have been implicated in triggering narcolepsy, but the role of the adjuvants in the vaccine is still unclear (Gilbert 2012; De la Herrán Arita, Kornum, Mahlios et al. 2013; Miller, Andrews, Stellitano et al. 2013).

\section{METHOD AND AIMS}

The ethnological research project "Epidemics, Vaccination and the Power of Narratives" started in 2013 to investigate cultural and social framings concerning the $\mathrm{A}(\mathrm{H} 1 \mathrm{~N} 1)$ pandemic and the vaccination measures in Sweden. The overall aim of the project is to enhance knowledge about the implications of culture (cf. Lindenbaum 2001; Atlani-Duault and Kendall 2009; Singer 2009) among different categories of people, such as patient groups (both with swine flu and narcolepsy), social and medical authorities and policy-makers, and healthcare workers.

The main material for this article consists of eight interviews with parents of children suffering from narcolepsy as a side effect of Pandemrix vaccination. ${ }^{6}$ The parents were recruited with help from the Association for Narcolepsy and advertisements in daily 
newspapers. The interviews were complemented by participation in a meeting with a national expert group on narcolepsy and a three-day period of observation in July 2014 when the Association for Narcolepsy participated at the annual national political event, Almedalen Week in Visby, Gotland county. Almedalen Week is a 46-year-old political and democratic tradition in Sweden, starting in 1968 with Olof Palme, prime minister at that time, speaking from the back of a lorry at Almedalen. The political speeches have developed into Sweden's biggest political meeting place which gives everyone who wants to debate social issues the opportunity to take part. In 2014 there were almost 3500 political, educational and cultural events going on during the week. (www.almedalsveckan.se). Presenting their causes during this kind of event provided an important and strengthened opportunity for public action for the Association for Narcolepsy.

The parental experience of "waking up to narcolepsy" (Hauser and Johnston 2011:A5) after the national mass-vaccination intervention created a starting point for a collectively shaped narrative whose main function was to take a critical stance in the public debate over the vaccination program. This critical and politically engaged narrative formed an underlying 'sounding-board' during my interviews. In this article, I intend first to describe this critical narrative and to show some of its enactments in public space. The second aim is to present a more person-centered approach to examine how the consequences of the disease have been experienced, especially in terms of learning and teaching among parents and the afflicted children. This didactic functionality evolved in the face of the children's' conditions and resulting disruptions of family life and led to the development of coaching and facilitating interactions with their children. In combining these two approaches, I refer to Daniel Touro Linger's concepts of 'public worlds' and 'personal worlds', and his understanding that "human worlds cannot be fully understood without reference to both" (Linger 2005:12). The critical narrative typically addresses the public world with its politicians, authorities, 
bureaucracies, and media. The person-centered ethnography sheds light on individual and family-based meaning-makings that have the capacity for continual learning (Linger 2005:18).

Because a vaccine had caused the children's narcolepsy, these families formed a new organization - the Association for Narcolepsy - instead of joining the national neurological patient organization to which those who develop narcolepsy for other reasons belong. The association started in 2010 as a continuation of earlier Facebook contacts between parents. The work has expanded both nationally and internationally, and has three primary goals: 1) to influence researchers and decision-makers to find a cure or treatment for narcolepsy that works; 2) to make it possible for those who developed narcolepsy after vaccination with Pandemrix to get economic compensation; and 3) to build networks, spread knowledge, provide support, and arrange meetings for patients and their families (http://www.narkolepsiforeningen.se/). Many parents were active participants in the association. Some placed their energy in working with the media, some with legal and bureaucratic procedures, some tried to get the attention of politicians, and some tried to understand and contribute to the medical research about the disease. Several meetings have been organized for patients and their families that have aimed to provide information and an exchange of experiences. The association has also worked closely with Agrenska, a national center for rare diseases (www.agrenska.se) . On their own, the families and the young narcoleptics experienced what Kaethe Weingarten has described as low 'narrative resonance', i.e., very few people around them knew how to respond when they initially mentioned the name of the disease or described the symptoms. The meetings with other narcolepsy families, however, turned into arenas where coherent narratives could develop (Weingarten 2001, cf. Culbertson and Bruck 2005:19). 
The interviews were shaped as informal, open-ended conversations (Linger 2005:52) with either fathers or mothers or, on occasion, with both parents at the same time. Their narcoleptic children (who did not participate in the interviews) were aged between 6 years and 14 years at the time of vaccination in the autumn of 2009 and, therefore, were almost 4 years older at the time of the interviews. The interviews were held either in the parents' homes or at different public spaces. All informants were eager to know why I was interested in their personal stories and what I would do with the material. Most of them were very positive about me being a researcher and having travelled a long distance to meet them: "You come here to our home ... this enables trust, a light at the end of the tunnel" (interview Peter, May 20, 2013).

At times it appeared that the interviewees hoped that I would become a new kind of 'authoritative voice' to represent them (cf. Frank 2010:31), but they were all informed that my research had a cultural scope rather than aiming for political or medical results. Some contrasted my efforts with the reluctance or the lack of effort they had experienced from different officials, experts, and politicians. My position as researcher and dialogue partner could, therefore, become ethically complicated. Sitting silently, nodding, and listening could be taken as factual consent, although I was not at all sure about my own standpoint in the complicated web of interpretations. In the end, however, my intention was not to question their interpretations, but rather to make sure I understood what they wanted me to understand (cf. Manderson, Bennett and Andajani-Sutjahjo 2006).

\section{SHAPING A POLITICAL AND CRITICAL NARRATIVE}

In her wish list to Santa, 10-year old Anna wrote about her sharing experiences with many other children. This sense of collective experiences was also manifest in the parents' narratives. The parts of the interviews concerning the symptoms (fatigue, cataplexies, 
hallucinations) were mostly identical to each other and to the biomedical descriptions of narcolepsy. The similarities are easy to explain because they all describe a side effect from a national mass-vaccination intervention. Although some interpretations differed from person to person, the overall critical narrative concerned a sense of being pushed into a normative decision about vaccination, the difficulties with the prolonged diagnosis procedure, the struggle for getting proof of the association with the vaccination, and the distress about the authorities' responses or, more often, lack of responses.

The threat of the pandemic, especially to young people, had specific impacts on both governmental recommendations and individual decisions concerning vaccination. The parents' decision about vaccination were often described as quite easy, and most parents considered vaccination as a reasonable preventive measure for the child's health. It was also apparent, however, that they felt influenced by medical and political authorities' arguments concerning responsibility and solidarity with those who were unable to take the vaccine. Getting vaccinated became a way of showing responsible citizenship in the face of a pandemic threat. The emotionality of the solidarity argument in the context of a Scandinavian welfare state together with the citizens' obedient or positive response could be labeled as a “core of common sense" (Linger 2005:81). In hindsight, the parents' accounts contained a strong critique of the use of solidarity arguments that led to parents feeling emotionally trapped. This perceived trap was the main focus in the quest for justice after having put their children "on the sacrificial altar," as it was sometimes expressed.

All parents described the children's first symptoms as severe fatigue and difficulties staying awake during the day. In some cases, the children's teachers had contacted the parents to report that their children were suddenly and repeatedly falling asleep at school. Attacks of cataplexy were often followed by extreme fatigue. When consulting their doctor, the most common explanations were seasonal fatigue or pre-pubertal fatigue, followed by 
advice concerning sleep hygiene. All interviewees described the drawn-out process of gaining a final diagnosis of narcolepsy (cf. Marcovic, Manderson and Quinn 2004). With help from friends and relatives and from the Internet, the parents suggested a diagnosis of narcolepsy to the doctors, but this was usually rejected as unlikely because narcolepsy is so rare. The medical diagnosis was essential because it was instrumental (Dumit 2006; Louhiala 2010:83) in starting the bureaucratic and medical process, carried out by the Swedish MPA, to establish the connection with the Pandemrix vaccine. This process for determining causality led to a painful waiting experience for the families, and for some families it is still not over.

There are few rules regarding compensation and support for the families and the children. In the absence of clear regulations, parents were left to negotiate their individual needs with different officials and authorities. These negotiations were described as a continuous effort to gain recognition. The first struggle after having fought for a diagnosis was to have causality determined by the MPA, and this was followed by negotiations with the Pharmaceutical Insurance and The Swedish Social Insurance Agency. Finally, the parents had to contend with schools and teachers regarding special needs, for example, in athletics or other activities that could cause cataplexies or in making provisions for the children to sleep for a while during parts of the school day. Some parents reported that barriers to gain recognition and support were almost insurmountable, and in the end it became a question of which parents were insistent enough and capable of managing the negotiations.

Many families faced considerable economic and practical difficulties. It was not always possible, for example, for a parent to keep on working full time or to spend time traveling to work, as they used to do. Although this was described as a problem for some parents, their most important concern was to point out inequalities and what they considered to be the authorities' lack of understanding that there were families that were worse off than themselves. Some also worried about those who failed to have an affirmative decision from 
the case causality assessment. This assessment was made by the MPA after the general association with Pandemrix was proven. Each new case diagnosed with narcolepsy went through an individual causality assessment system (http://who-umc.org/Graphics/24734.pdf) with six causality categories ranging from "Certain" to "Unassessible/Unclassifiable". According to some parents it was necessary for them to influence the judgment by authoritative documentation of symptoms and thorough descriptions of intervals of time from vaccination to onset of symptoms. The worry was about those parents not being able to accomplish this. These worries are connected to lay perceptions of vulnerability and provided a sense of a shared problem that should be acted on collectively (cf. Stephenson, Davis, Flowers et al. 2014).

\section{ENACTING THE CRITICAL NARRATIVE}

I spent three days in the beginning of July 2014 at Almedalen Week in Visby in Gotland County. I was invited by the Association for Narcolepsy to speak about my research and to spend time with some of the parents and children. During the three days, I met many of the parents, including those I had interviewed earlier and those who were new acquaintances. All parents and children were dressed in yellow t-shirts that said, "We are taking the consequences. Who is taking responsibility?" The purpose of the association's participation at Almedalen was clear. This big national political event was an opportunity to reach as many politicians, officials, and media as possible with their message and to pull back the curtain of silence that they feared had covered the issue now that over four years had passed since the vaccination program.

The different performances by the parents and the teenaged children acted out every detail of the critical narrative found in the interviews. These enactments were concentrated in three places - the information tent, the accommodation where the children 
slept (which was also the place for public seminars and my lectures), and the Speaker's Corner at a central square where narcoleptic teenagers performed every day throughout the week.

I often visited the information tent. The parents had drawn up a timetable for the whole week for them to be present in the tent talking to people, handing out information, and answering questions. In the tent, there was also a bed where a young narcoleptic was almost always sleeping, sometimes using a heavy chain blanket to be able to have a deep sleep. The blanket consists of several lengthwise chains placed in certain canals. The blanket is used in order to relax, calm down and improve sleep. I also spent time in the accommodation where 10-15 young girls and boys lived during the week. Some of the teenagers had met before and were already friends; some were newcomers. Of course, all had different backgrounds, concerns, and dreams for the future, but the disease had made their lives and experiences in many ways similar; this was their main topic of conversation and helped establish new friendships (cf. Desjarlais 1996, Hollan 2012). Most of the parents spent time in the accommodation, although they had other places to stay at night. They talked to one another about their everyday lives, about the illness, and about the children. They laughed and joked and discussed strategic plans for making the best out of the week. One or more of the children were intermittently sleeping on their air mattresses that were brought for them. The sight of their young ones sleeping during the day had become normal for the parents, and nobody commented on it or tried to speak quietly around them. They waited for their children to wake up, to take their medication, and to start preparing the different assignments that they had - to be around in the tent, to walk in the city with their t-shirts on, and to make their daily performances on Speaker's Corner. I saw them doing this performance twice. In the first performance, the teenagers interviewed each other on stage. Some stood alongside the podium 
holding up a sign with information and some handed out brochures about the association and about the disease.

The second performance that I attended has stayed in my mind. Before this performance I was interviewing one of the girls who was to be on stage. She was 19 years old and had gotten her diagnosis quite recently. She was crying a lot during the interview, and her voice was weak and her body trembled. I was worried about her and wanted to stop the interview to give her time to prepare for the performance, but she wanted to carry on. An hour after we ended our talk, I saw her on the podium at Speaker's Corner together with three others. I had trouble recognizing her as the same person. Her voice was strong, she handled the microphone and the audience as a professional, and she caught the attention of those nearby on the square. She talked about the decision to get vaccinated, she talked about solidarity and responsibility, she talked about her brain damage, and she talked about her worries about the future as a creative artist. Her attacks of cataplexies when she started speaking made her whole body tremble, and the other three on the podium had to hold her up. Some parents asked them to finish, but they wanted to go on. Several people stopped to watch and listen, and several people cried. Many took the information brochure, and some of those in the audience came to listen to my lecture the next day.

The critical narrative was performed in many ways at Almedalen, both verbally and in silent communications. The Speaker's Corner presentations were the most dramatic and 'efficient' demonstrations that caught many people's attention. The specially staged situation at Almedalen - the thousands of events and hundreds of journalists - made it possible to present the living dramas to an audience (cf. Riessman 2003), but they could also become lost in the ever-changing flow of happenings and events. Despite of the heavy competition for attention, the parents felt that communicating the need for social justice was an important accomplishment and plans started to grow for participating the next year. 


\section{NARRATIVES OF CONTINUAL LEARNING}

The main purpose of communicating the critical narrative was to make a compelling political argument, and the functions of other narrations were to show, to teach, and to increase the understanding of the nature of everyday life with a narcoleptic child. Thus I will turn here to the interviews with the parents Marianne, Frej, and Greta to show their continuous learning (and teaching) experiences. These topics were present also in other interviews, but Marianne, Frej, and Greta were the most eager of all the parents in putting them forward.

Marianne lives in the countryside outside a small city in the south of Sweden. I travelled by plane to a city nearby her home and met her at my hotel. She told me about her being married and having three sons. She described her oldest son with the word 'diesel', which was a way for her to jokingly point out his main interests in engines, tractors, and big machines. Her youngest son has Down's syndrome, and the son in the middle, Martin, had got narcolepsy. They have a family-owned agricultural business and she also works as a clerk at an engineering company. She appeared certain of her prioritizations and of her conviction that everyone has his or her own responsibility for the choices they make. When news about the pandemic came out, and when the recommendation for mass-vaccination was made, they thought about it very carefully and tried to evaluate different sources of information. She was somewhat hesitant and afraid of complications, and some of their friends advised them not to have the children vaccinated.

I remember us sitting there, me and my husband, by the kitchen table late at night, and really decided 'yes, we're gonna do this'. We didn't do it just out of routine, we really thought about it and discussed it back and forth. And OK, now 
we have this problem also, we will have to manage it in any way we can (interview Marianne, March 5, 2013).

Frej is a business attorney who is married and has three sons who all got vaccinated, but only the youngest, Glenn, got narcolepsy. Frej's main interest in the association concerns judicial matters and media communications. I met him at a café in the city where he works. He told me that he and his wife take on different roles. His main concern is to coach his son Glenn to find ways to cope with the paralysis and the hallucinations. His wife helps Glenn with schoolwork and with social relations. She was very active in promoting the vaccination, and according to Frej she blames herself and she "will never forgive herself through her whole life." He keeps reminding her that it was especially important for Glenn to get the shot because he suffered from asthma, but she continues to blame herself.

Greta is the mother of Maja, who was 18 at the time of the interview. The interview took place in Greta's home. She is divorced from Maja's father and is now married to another man. Maja's father opposed the vaccination, but Greta - who describes herself as 'obedient' - wanted to follow the state recommendations. Maja was the first child in Sweden to be diagnosed with narcolepsy after vaccination. Greta also has two other children who were vaccinated but did not get narcolepsy. One of them suffers from diabetes, and this, together with the fact that Greta also has a medical education, explains why she does not suffer from feelings of guilt. As a parent, she finds the child's diabetes harder to handle mentally because it is a life-threatening illness with a thin line between life and death. In her mind, the experience of having a child with diabetes has helped her to put narcolepsy into perspective, and she also talks about her own and Maja's positive attitudes that have helped them a lot.

\section{The Handling of Cataplexies, Paralyses, and Hallucinations}


Most children and young adults with vaccine-associated narcolepsy have a more serious form of the disease than those not associated with vaccination (Szakács, Darin and Hallböök 2013:1315). Along with the sleep attacks, they had several cataplexies every day, sleep paralyses, nightmares, and hallucinations. All symptoms caused complicated emotional reactions. Marianne pointed out Martin's many daily cataplexies and how they made him feel ashamed, which in itself led to new cataplexies. Going outdoors demanded great mental preparation, and he had to be very prepared, alert, and decisive to go through with it. Martin was scared of not being able to keep his balance in the presence of other people. Falling would make him feel ashamed, and he told his mother that he tried to walk in a relaxed way to avoid falling so hard.

Having cataplexies meant losing control over the body and having a sense of separation between 'self' and body. Young people used different tricks to overcome this separation in order to gain control: "Some squeeze the thumb hard, some their toes, some bite their lip, some hold in their stomach" (interview Marianne). Frej told me that at family meetings the children found ways to make fun of their dysfunctions. They could be standing together each holding a glass of water, joking and laughing, to see who would have the first cataplexy and drop the glass. This was one example of many of how individuals found creative ways to handle the situation using dark humor (interview Frej, October 29, 2013). Frej also talked about his attempts at coaching his son and other young people in handling the symptoms, especially the paralyses and the hallucinations. His son Glenn was at first very reluctant to participate in the family meetings that were held within the Association for Narcolepsy, and to convince his father he texted him a message stating his reluctance to go “to a damn meeting with other people who are ill." Still, he went to the meeting and, according to his father, he was very happy with it. He met other young narcoleptics, and they stayed up late talking, joking, and laughing and intermittently falling asleep. After that first 
positive experience, he participated in many meetings arranged by the association and his father considered it to have been good for him. However, Glenn had a kind of backlash after a special meeting attended by many different psychological experts who talked about the disease. Frej explained how Glenn then felt 'disabled' and conscious of his dysfunctions and became depressed. This made him very low for a while, but Frej talked about his son's “iron will" and how Glenn decided that he has only one life and he has to live it. Glenn's choice was to have no medication for the cataplexies but to sleep at least three times every day. Besides the cataplexies, he had sleep paralysis and hallucinations almost every night and day. The hallucinations were horror-filled and mixed with nightmares. Sometimes he was convinced that the horror would still be there and he did not "dare to wake up". Frej tried to help him find a way to get back to sleep after waking up with the hallucinations and the horror: "I had at first no clue about what to say to him. Then I started asking why he doesn't use his superpowers ... Superman or Spiderman, why don't you use one of them? 'I don't know', he said, and then he fell asleep again.”

Frej's suggestion to make use of Superman or Spiderman was a way to invoke a kind of wakeful agency even if the nightmares showed the "inhabitation and involvement in worlds other than the waking world" (Williams and Crossley 2008:3, cf. Adler 2011). Together Frej and Glenn also tried to work out a tactic to handle the hallucinations that came when he was awake. He could, for example, be watching TV and suddenly his brother would come out of the TV to hurt him and Glenn would be paralyzed and unable to move. Glenn talked about his efforts to use his will to be able to break out of the paralysis, and Frej helped him in this thinking:

It's an assignment, or maybe a shared idea between us, that as soon as he has a sleep paralysis he should use his will and try to break it to see if he can get some 
other part of the brain to learn. ... He believes in it, he thinks it is possible. He thinks everything is possible, and what is impossible only takes longer.

The trust that Glenn and Frej presented in their enabling narratives was contrary to seeing themselves as victims and was a way to engage rhetorically in the consequences of the disease (cf. Napier 2003:68). Frej explained Glenn's refusal about surrendering to the disease: "Because then it would be the disease that decides, and he wants to be in charge."

Frej told many stories about how believing that tasks were possible or manageable made life easier for them both. Glenn had also commented on something he noticed when talking to other narcoleptic children: “Dad, it seems that the other children's parents are so bitter, so irritated. That must be really heavy, imagine how terrible it would have been for me if you had been like that." Frej decided to tell the other parents, which resulted in "I think all of us cried." The facilitating and coaching approach seemed to be the only one possible for Frej in relation to his child. His conclusion in the interview was:

When I think of Glenn I feel happy, even when I think of his future. When his mother thinks of him in the future she starts crying. I also almost start crying now when I talk about it. But I can’t do anything about him having the disease. I have to put my energy into making it as good as possible.

\section{The Issue of Medication}

At present, there is no curative treatment for narcolepsy. Treatment is palliative and focuses on managing and alleviating the symptoms. Personalized treatment is always necessary (Vetenskapsrådet 2012:18). Strong stimulants and antidepressants are used, but there is also a need to find behavioral strategies such as daytime naps, sleep hygiene, dietary restrictions, and so on. Because personalized treatment is necessary, it has led to a variety of opinions about existing types of medication. Some of the children and the parents were 
strongly hesitant towards drugs and wanted to take as few as possible. This choice was commonly understood as a consequence of experiencing the side effect of the vaccination. It was also grounded in disbelief in medication with a strong link to market interests and to risks of dependence with long-term consumption (Wolf-Meyer 2014:146). The hesitance mostly concerned GHB - or the 'date rape drug' - that is used to help patients to sleep for four-hour periods and to reduce the incidence of cataplexies (Wolf-Meyer p.149).

Greta had the opposite opinion and affirmed the need for medication, and this was woven into her narrative about her daughter Maja: "Maja suffers from a very severe form of narcolepsy. She is a wreck without medication - without medication she has no life ... and I really try to communicate that when I meet people that are negative to medication" (interview, August 23, 2013).

Greta encourages Maja to take all the medicines and not to be afraid, but she has met many young people who say they have decided to manage without pills:

And then I keep saying, think about this, you are 20 years old now and you will never be 20 again. Is it okay to live your life in a bubble and be deadly tired or is it better to medicate and have a better quality of life? ... And I have Maja to compare with. Her life is quite okay. It is still tough for her, but it is okay. She manages school. She works at a gym two nights every week.

Answering my question about why she had this positive attitude towards medication, she explained it using a perspective for the future:

If you imagine that the side effects from the medicine might shorten your life by five or ten years. Anyway, we don't know how long we will live, but I think it is better to have as good a life as possible when you are alive instead of living as long as possible. And we will put our hopes in research. 
Greta's attitude towards medication was confirmed in a Swedish radio interview $^{7}$ with one of the most prominent narcolepsy specialists, Professor Emmanuel Mignot at Stanford University, who is critical of Swedish clinicians for not prescribing enough effective medication to narcolepsy patients.

\section{The Disruption of Everyday Life}

The interview with Marianne provided details about how having a narcoleptic child in the family affected their normal routines. Changes in the spatial and temporal rhythms due to the remedies and therapies (Wolf-Meyer 2014:145) affected every family member as well as relations with friends and relatives. The sudden sleep attacks and cataplexies prevented her son Martin from traveling alone to school or taking part in activities outside the home. He had to be picked up and accompanied by his parents, his older brother, or an assistant. The few hours of wakefulness and alertness turned into a complicated piecing together of doing homework, eating, showering, and so on. Eating properly at the right time was described as a special problem because this was important for the state of wakefulness and the ability to concentrate. Her account of an ordinary day for her son was briefly described as follows:

Taking medicine in the morning, daylight lamp, breakfast. Long-term effective medicine before traveling to school. Sleeping in the car. Texting on arrival to the assistant at the school. Sleeping after the two first lessons. More medication. Picking him up in the afternoon, sleeping in the car. Small meal. Struggling to make him take a shower. Sleeping under a blanket of chains weighing $8 \mathrm{~kg}$. Trying to make him eat. Sleeping under a blanket of chains at about 7 or 8 in the evening. 
The bouts of sleeping and the interruptions to daily life that these brought were very obvious in Marianne's story. She worried about school and the future working life for her son. Sleep practices are, as Williams and Crossley point out (2008:6), related to wider patterns of social organization and different sleep cultures. Swedish society and its main institutions, are very much integrated with a monophasic sleep pattern (Steger and Brunt 2003), placing responsibilities on individuals to adjust their everyday life to fit into this. It is clear that the narcoleptics will face practical problems in school as well as in their future working lives due to their need for biphasic or polyphasic sleep unless there is a new understanding of alternative forms of sleep within society (Wolf-Meyer 2011:968, cf. Eugene 2013; Hollan 2013).

One of the complications from narcolepsy is a deficiency in rapid eye movement sleep that leads to aggressiveness, emotional outbreaks, and severe cognitive difficulties. Marianne talked about how Martin's younger and older brothers were drawn into the emotional warfare. The older brother was sad because there was no time anymore to do things with his father the way he could before. Feeling irritated and disappointed, he accused his narcoleptic brother of taking advantage of the situation. The relation with the younger brother with Down's syndrome also became complicated: "His little brother turned on the smoke detector once and it took hours before Martin could act normally again. He was very scared, he was completely knocked-out. He would never be able to make his way out if there was a fire or something."

This quotation also shows one of the main components in Marianne's and other parents' narratives - how the disease had made children unable to manage on their own.

He can't cook an egg, or fry an egg or anything like that because he can't handle the buttons on the stove. If something would scare or upset him and he had to handle it quickly, he wouldn't manage it. ... and you have to check on 
him when he is showering, or listen, so he doesn't fall. To take a bath in the tub is out of the question.

The description of how children had been earlier - clever, bright, and alert children who could handle very much on their own - was contrasted with the present state of disabilities, emotional instability, and complete dependence on other people. But even if Marianne stressed the dysfunctional aspects, she had an obvious didactic approach in her accounts. She had a strong urge to be able to explain the details of the disease and make other people understand. Working in an environment with engineering mechanics, she also constructed her own kind of metaphor (cf. Quinn 1991:65, Napier 2003:68) to visualize what had happened in the brains of the children: "They are like a trailer coupling, have you seen one of those? Do you have a car with a trailer? You know there are lots of these (showing cables with her fingers) and it is kind of completely burnt ... it is unrepairable and the plastic is burnt and everything is helter skelter." The choice of trailer couplings as a metaphor was logical according to her already existing cultural understandings (Quinn 1991:65). The trailer metaphor made immediate sense to her, and also to me. It also pointed out the difficulty of how to handle the condition. I asked her what she thought about "mending" such destroyed couplings. What could be done if everything was completely burnt? She hesitated, but just like Frej, she suggested there could be a way of finding other connections in the head or, now escaping her metaphor, "strengthening other senses".

What was very apparent in the narratives was that although almost four years had passed they were still mourning the loss of the child that was. The sorrow was also about a lost life with friends and neighbors (cf. Culbertson and Bruck 2005). After I had turned off the tape recorder, Marianne wanted me to turn it on again so she could make me understand how families could become socially isolated because of the disease. Her family had lost 
friends and she explained this by her unwillingness to hide the problem from other people. She wanted to talk about their problems and this "scared them off:"

Our old friends that we used to have, when they meet us and listen to our problems, they feel guilty and they just cannot face that we are struggling so hard. Because we have become ill and they have remained healthy and can continue their lives. ... Because they ask how we are, and I don't say that everything is fine ... No, I start babbling about it all, about the terrible paperwork that we need to fill in and everything that we need to appeal. ... No, we have basically no friends, we don't intermingle. And I feel that I would really like talking with a neighbor over the fence and complaining about the lawnmower. I would fancy those kinds of problems!

\section{CONCLUSION}

The narratives presented and enacted by both parents and teenagers showed how the narcoleptic experiences involved both public and personal worlds. Quoting Linger, public worlds are "environments to which people are exposed, into which they are thrust, or which they build together, and from which people learn, over the course of their lives, to assemble ever-changing universes of thought and feeling." (Linger 2005:12). The critical narrative created by the parents typically addresses the public world - the enactments at the Almedalen week being the most obvious examples. The person-centered ethnography showed families' active meaning-making practices (Linger 2005:18) through individual and collective learning on how to handle their disrupted family lives, finding strategies such as using dark humor, cognitive tricks, and making themselves and their children's bodies both objects and subjects of knowledge. 
The Association for Narcolepsy works in the "light of the causes they defend" (cf. Akrich et al. 2013:12) - causes being results of the continuous learning experiences. It is clear that these experiences also had been transferred into the agenda of the national expert group where the Association for Narcolepsy is one of the participants, together with national authorities, neurological clinicians, and researchers. I had the opportunity to attend at one of the meetings of the expert group in April, 2014. It was obvious that the experiences made by families and their association had the potential to function as a mediating tool between credentialed and experiential knowledge (cf. Rabeharisoa, Moreira and Akrich 2013). Several issues were treated, such as the prolonged bureaucracy concerning support and compensation and the need for further research about causes, treatments, and care. The creation of a qualitative narcolepsy register for patients and clinicians to monitor the disease was discussed as on its way. The particular circumstances in the handling of rare diseases, including the knowledge gap created when patients have to move from care from a pediatric neurologist to a neurologist for adults, was pointed out as another obstacle for patients because they will have to deal with a new set of clinicians who lack sufficient knowledge of the disease. Other issues came up, such as the need to facilitate children in school and in their future work. This drew research on sleep and the socio-cultural understandings of sleep into the discussion.

The potential of the parents' participation in this mixing of personal worlds and public worlds, including the entanglements of knowledge work and political work (Akrich et al. 2013:12), is still to be fully explored, as is its ability to lead to 'evidence-based activism' as described by Rabeharisoa et al. (2013). It remains obvious that the families' and the children's contributions have been, and will continue to be, essential.

The cases of narcolepsy illustrate significant personal and familial suffering, and they demonstrate how severe side effects can still occur despite (or, maybe ironically caused by) Sweden's highly efficient pandemic preparedness. Without global and national pandemic 
preparedness, without a well-planned purchase agreement with vaccine producers, and without a successful implementation, these adverse effects would not have appeared (Socialstyrelsen 2011). This situation was expressed from a high-ranking Swedish health official who praised the pre-pandemic planning but regretted the side effect:

We had worked out a good plan with the county councils ... and that was why we were so successful. The whole of Europe was wondering - 'How did you manage?' So, what would have turned out to be a success story became an Achilles-heel when it was shown that the vaccine had such serious side effects (interview, February 27, 2013)

In this article my intention was to center a side effect, this narcoleptic Achillesheel, to show the consequences for the affected group and its individuals. All parents who I met stressed their sense of social responsibility, not only towards their own families and children but also towards other parents, other families, and other children. None of them opposed vaccination in general, and none would place themselves in an anti-vaccination movement, although this experience with narcolepsy had strengthened their doubts about future vaccination for themselves and their children. Despite the strong critical narrative, the association has made it clear that their aim is not to polarize the relationship between doctors and patients or between families, authorities, and politicians. This intention is a sign of both individuals' and the association's ability to find a way to balance the critical narrative in order to translate it into constructive action - a process I would define as reflective consciousness (Linger 2005:20. This also opens for pondering the potential of reflective consciousness within the public spheres of pandemic preparedness planning. This reflective learning is about the conscious questioning and transformation of well-established common-sense truths about measures in case of emerging influenza pandemics. A person-centered ethnography using specialized interviewing and observational practices (Linger 2005:15) within groups of 
politicians, officials and policymakers carries a potential to consider reflective consciousness as a means of creating a more participatory prepared implementation of different practices within communicable disease control.

\section{ACKNOWLEDGEMENTS}

I am grateful to the Association for Narcolepsy for information, to the parents who allowed me to interview them, and to officials at the National Board of Health and Welfare, the European Centre for Disease Prevention and Control, the Medical Products Agency, and the Swedish Institute for Communicable Disease Control for providing information. I am also grateful to the editor and the three anonymous reviewers for their very helpful and constructive review and suggestions. Ethics approval was from the Regional Ethical Review Board, May 29, 2012. (Dnr2012-133-31).

\section{FUNDING}

Research and writing was supported by the Marcus and Amalia Wallenberg's Foundation in Sweden.

\section{NOTES}

\footnotetext{
${ }^{1}$ In November 2013, a European alliance with members from the UK, Sweden, Ireland, Finland, and Norway was formed. http://www.narcolepsy.org.uk/news/press-release-neweuropean-alliance-meets-discuss-impact-swine-flu-vaccine-pandemrix-children-1

${ }^{2}$ In Sweden there are no mandatory vaccinations, not even for the child immunization program. Nevertheless, the coverage of vaccination is very high at over 98 percent for children's vaccination.
} 
${ }^{3}$ www.lakemedelsverket.se./Alla-nyheter/NYHETER-2011/Rapport-fran-

fallinventeringsstudie-om-Pandemrix-och-narkolepsi/.

${ }^{4}$ http://www.lakemedelsverket.se/english/All-news/NYHETER-2013/Registry-study-

confirms-increased-risk-of-narcolepsy-after-vaccination-with-Pandemrix-in-children-and-

adolescents-and-shows-an-increased-risk-in-young-adults .

${ }^{5}$ The vaccine Pandemrix was used in 38 countries, but other vaccines were also used. See $\underline{\text { http://www.ecdc.europa.eu/en/healthtopics/pandemic preparedness/pandemic_2009_evaluati }}$ ons/Pages/pandemic_2009_evaluations.aspx for details. Sweden had an advance purchase agreement with GlaxoSmithKline (18 million doses - two doses for each citizen). When WHO declared phase 6 of the pandemic, the built-in trigger was pulled to call the agreement.

${ }^{6}$ The informants (pseudonyms) and the children (pseudonyms) and ages at the time of vaccination: Cecil, father of Erika 11; Marianne, mother of Martin 12; Peter, father of Filip 7; Greta, mother of Maja 14; Lydia, mother of Nils 6; Frej, father of Glenn 12. 


\section{REFERENCES}

Adler, S.R.

2011 Sleep Paralysis. Night-mares, Nocebos, and the Mind-Body Connection. New Brunswick, NJ; London: Rutgers University Press.

Akrich, M., O’Donovan, O. and V. Rabeharisoa

2013 The entanglement of scientific and political claims: towards a new form of patients' activism. Working Paper 13-MS-07. Paris, France: Centre de sociologie de l'innovation.

Atlani-Duault, L. and C. Kendall

2009 Influenza, anthropology, and global uncertainties. Medical Anthropology 28(3):207-21.

Culbertson, H. and D. Bruck

2005 Narcolepsy and disruption to social functioning. Applied Psychology (clinical section) (1(1):14-22.

De la Herrán-Arita, A., B.R. Kornum, J. Mahlilos, W.Jiang, L.Lin, T.Hou, C. Macaubas et al.

2013 CD4+ T Cell autoimmunity to hypocretin/orexin and cross-reactivity to a 2009 H1N1 Influenza A epitope in narcolepsy. Science Translation Medicine 5 (216) 1-13. 
Desjarlais, $\mathrm{R}$.

1996 Struggling along. In Things As They Are: New Directions in

Phenomenological Anthropology. M. Jackson, ed. Pp. 70-93. Bloomington IN:

Indiana University Press.

Dumit, J.

2006 Illnesses you have to fight to get: facts as forces in uncertain, emerging

illnesses. Social Science \& Medicine 62(3):577-590.

Eugene, N.

2013 Working while narcoleptic. Anthropology of Consciousness 24(2):158-171.

Frank, A.W.

2010 Letting Stories Breathe. A Socio-narratology. Chicago,IL: The University of Chicago Press.

Gilbert, S.C.

2012 Influenza vaccines and immunopathology. Expert Reviews Vaccines 11:873-5.

Hauser, S.L. and S.C. Johnston

2011 Waking up to narcolepsy. Message from the Editor. Annals of Neurology 70;3:A5-A6 
Hollan, D.

2012 On the varieties and particularities of cultural experience. Ethos 40;1:3753.

2013 Sleeping, dreaming and health in rural Indonesia and the urban U.S.: A cultural and experimental approach. Social Science \& Medicine 79:23-30.

Lindenbaum, $S$.

2001 Kuru, prions, and human affairs: Thinking about epidemics. Annual Review of Anthropology 30:363-385.

Linger, D.T.

2005 Anthropology through a double lens. Public and personal worlds in human theory. Philadelphia, PA: University of Pennsylvania Press.

Louhiala, P.

2010. What do diagnoses mean, and does it matter? In Diagnosis. Eds. P R.Ahlzén, M. Evans, P. Louhiala and R. Puustinen, Pp. 76-88. Medical Humanities Companion, vol.2. Oxford, UK: Radcliffe Publishing.

Manderson, L., Bennett, E. and Andajani-Sutjahjo

2006 The social dynamics of the interview. Qualitative Health Research 16 (10): 1317-1334.

Marcovic, M., Manderson L. and Quinn, M.

2004 Embodied changes and the search for gynecological cancer diagnosis. Medical Anthropological Quarterly 18(3): 376-396. 
Miller, E., N. Andrews, L. Stellitano, J. Stowe, A.M.Winstone, J.Shneerson, C. Verity. 2013 Risk of narcolepsy in children and young people receiving AS03 adjuvanted pandemic A/H1N1 2009 influenza vaccine: retrospective analysis. British Medical Journal 346:1-11.

Napier, D. A.

2003 The Age of Immunology. Conceiving a Future in an Alienating World.

Chicago, IL: The University of Chicago Press.

Quinn, N.

1991 The cultural basis of metaphor. In. Beyond Metaphor: The Theory of Tropes in Anthropology. Ed. J.W Fernandez. Pp. 56-93 Stanford, CA: Stanford University Press.

Rabeharisoa, V., Moreira, T. and M. Akrich

2013 Evidence-based activism: Patients' organisations, users' and activist's groups in knowledge society. $N^{\circ}$ 033. Paris, France: Centre de Sociologie de l'Innovation.

Riessman, C. K.

2003 Performing identities in illness narrative: masculinity and multiple sclerosis. Qualitative Research 3:5-12.

Singer, $\mathrm{M}$.

2009 Pathogens gone wild? Medical anthropology and the "Swine Flu" pandemic. Medical Anthropology 28(3):199-206. 
Szakács, A., N. Darin, T. Hallböök

2013 Increased childhood incidence of narcolepsy in Western Sweden after H1N1 influenza vaccination. Neurology 80(14):1315-1321.

Socialstyrelsen

2011 A(H1N1) 2009. An evaluation of Sweden`s preparations for and management of the pandemic. Stockholm, Sweden: The National Board of Health and Welfare.

Steger, B. and L. Brunt, eds.

2003 Night-time and Sleep in Asia and the West: Exploring the Dark Side of Life. London: Routledge Curzon.

Stephenson, N., M. Davis, P. Flowers et al.

2014 Mobilising "vulnerability" in the public health response to pandemic influenza. Social Science \& Medicine 102:10-17.

Vetenskapsrådet

2012 The Swedish Research Council’s mapping of research relevant to the etiology and treatment of the disease narcolepsy. Stockholm, Sweden.

Weingarten, $\mathrm{K}$

2001 Making sense of illness narratives: Braiding theory, practice and the embodied life. http://www.dulwichcentre.com.au/illness-narratives.html

Wijnans, L., C. Lecomte, C. de Vries, D. Weibel, C. Sammon, A. Hviid, H. Svanström et al. 2013 The incidence of narcolepsy in Europe: Before, during, and after the influenza 
$\mathrm{A}(\mathrm{H} 1 \mathrm{~N} 1)$ pdm09 pandemic and vaccination campaigns. Vaccine 31:

1246-1254.

Williams, S.J. and N. Crossley

2008 Introduction: Sleeping Bodies. Body \& Society 14 (4):1-3

Wolf-Meyer, M

2011 The Nature of Sleep. Comparative Studies in Society and History 53(4): 945-70.

2014. Therapy, remedy, cure: Disorder and the spatiotemporality of medicine and everyday life. Medical Anthropology 33:144-159. 